\title{
The Key Criteria in Deciding to Tender for Construction Projects
}

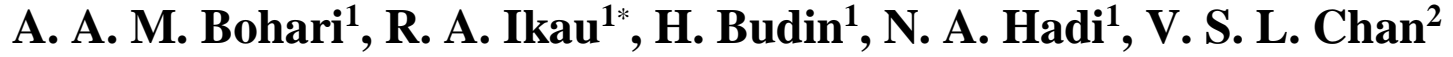 \\ ${ }^{1}$ Faculty of Architecture, Planning and Surveying, \\ Universiti Teknologi MARA, Cawangan Sarawak, 94300 Kota Samarahan, Sarawak, Malaysia \\ ${ }^{2}$ Academy of Language Studies, \\ Universiti Teknologi MARA, Cawangan Sarawak, 94300 Kota Samarahan, Sarawak, Malaysia \\ *Corresponding Author
}

DOI: https://doi.org/10.30880/ijie.2021.13.03.028

Received 05 January 2021; Accepted 13 May 2021; Available online 10 June 2021

\begin{abstract}
Planning for a construction project is a formidable task which involves a huge investment with multiple stakeholders such as clients, consultants, and contractors. A tender is a submission of a technical, administrative, and contractual material made by a potential contractor in response to an invitation to tender by the project client. Established contractors normally realise the importance of doing initial research before committing themselves to enter the tender. Normally, tender pre-qualification is a strict process. A low-quality tender submitted due to problems such as insufficient time and incomplete tender documents normally lead to tender rejection by the client. Thus, this research aimed to provide a strategy to help the contractors in deciding whether they should or should not submit a tender at the initial tendering decision phase. The literature review was focused on the key factors identified in influencing the decision-making process and in the final part, the initial conceptual model was established
\end{abstract}

Keywords: Tender, construction industry, criteria

\section{Introduction}

Construction Industry Development Board (CIDB) expected the construction industry to grow by $8 \%$ in 2017 and that reflected a total value of RM170 billion, fortified by numerous mega infrastructure development projects that also helped the economy flourish. This was an increase from 2016 when the industry recorded a total value of RM166.4 billion, reflecting a growth of 7.4\% [1]. This upward trend continued in 2019. The Malaysian Department of Statistics provided data that showed the increase of Gross Domestic Product (GDP) from the second quarter of 2019 with RM16.06 million to RM16.95 million in the third quarter of 2019.

The construction industry is crucial to enhance and improving economic development, which is aligned with the theme of the Eleventh Malaysian Plan (11MP) 2016-2020, anchoring growth on people. The plan included three major components: people as the nation's bedrock, preparing them for the future, and everyone enjoying growth and development. From 2016 to 2020, the Malaysian construction industry was expected to contribute 5.5 percent to GDP [2]. Under Thrust 3, Construction Industry Transformation Programme (CITP), productivity was highlighted as the main concern to move the construction industry in Malaysia towards better output. In relation to that, various efforts were introduced and that included the Fourth Industrial Revolution 4.0 (IR 4.0) roadmap for the construction industry in January 2020. The roadmap mapped future programmes related to IR 4.0 for example developments of electronic applications and Building Information Modelling (BIM) [2]. 
With that, the industry is now calling for innovative ways to transform the industry from manual handling to enhancing the adoption of electronic application and digital information throughout the life-cycle of a construction project. The inclusion of IR 4.0 within construction processes will help to expedite the process, improve efficiency in terms of design and management and reduce operating cost. The roadmap also promoted cloud-based platforms to improve the ability of data management efficiency with the team and the project itself. Construction industry was always associated with fragmented management and temporary teams. These characteristics normally caused the industry to suffer from problems such as poor data retention and management, slow data transfer and inefficient data storage. Thus, this paper highlighted the need for incorporating e-based management in the tendering stage. However, the focus is on producing the tools for the tenderers to be able to assess their ability to tender before entering the actual tendering stage and providing the report to the client as the evidence.

\section{Tendering in Construction Phase}

Planning a construction project involves huge amount of money and it is a challenging task which required cooperation from all stakeholders in the project - clients, design teams, and contractors. The successful implementation of construction projects is strongly influenced by "making the right decisions at the right time". Therefore, efficient decision making by the client, the project consultant or contractor is essential. There are several contractor selection methods for the project which included tender selection, discussion, and direct selection. In most cases, the tender selection method is preferred because it is competitive. Tender prices are still a major issue despite the emphasis on contractor selection requirements based on "value". The tendering phase in the construction industry is the most crucial throughout the life cycle of the construction project because it shapes the contractual and legislative agreements among project stakeholders, and it has the cascading effects on the performance of the project after the tendering stage.

Malaysian Contract Act 1950 states that "all agreements are contracts if they are made by the free consent of parties competent to contract, for a lawful consideration and with a lawful object, and are not hereby expressly declared to be void". Therefore, a contract is said to be valid is when there is an agreement, consent of the parties, consideration made for a lawful object, and between the competent parties. In a construction contract, the relationship between clients and main contractors begins during the bidding process, for example the tendering stage. In the traditional process of tendering for construction projects, the client publishes a tender advertisement on the publicly accessible mass media such as newspapers and websites to inform the public pertaining to the tender proposal.

At this stage, the contractor submits the tender to the client, which is an offer to the client. When the contract takes effect, the contractor and client are bound as contracting parties [3]. Then, the client issues a letter of acceptance. The contract bonding ends when both parties have fulfilled their obligations, as stated in the contract. In standard construction contract practice, after the final payment is made to the contractor, the client will issue the certificate of practical completion.

When the contractor submits a tender to the client, the tender submission will be evaluated by the appointed tender board. The evaluation will be carried out in two stages and the list of qualified contractors will be issued. In the first stage, the completeness of the documents and the cut-off price are checked. This stage helped to screen out the tenderers and eliminate the unacceptable tender price. In the second stage, the technical evaluation is performed to test the contractor's technical ability to carry out the project. The highest tenderer based on the ratings in Stages 1 and 2 will be recommended as the successful tenderer.

\section{The key Criteria in Deciding to Tender for Construction Projects}

Most building projects are carried out using the open tendering system. There are three basic tendering processes that included open tendering, selective tendering and negotiation [4]. The system provided the elements of competitiveness and value for money. Handling of tendering procedures are often very complex as it involved many tasks with various groups and individuals. Different individuals have different priorities and objectives in bidding for the tender. For example, a contractor will have to determine either to participate in the tender or not depending on their current capability in terms of financial health and availability of expertise.

An accurate decision making during the tender process would strongly influence the success rate of a construction project implementation. Dealing with the tender procedure is complex and unpredictable [5] because it involves organization many tasks and individuals with different priorities and objectives. Biased and inconsistent decisions are inevitable if the decision-making process is entirely dependent on intuition or, subjective and emotional judgement. Tendering offers a competitive way to get contract work [4].

The decision to tender or not is based on the contractor's current ability and willingness. In the case of a contractor willing to submit a tender, the tenderer needed to ensure that the tender will be profitable and manageable [6]. The construction industry players' main conflict is that competitive bidding pushes the bid to be low enough in order to win the contract. Contracting organisations typically adopt pricing strategies by reducing the overhead and profit margins to the minimum that they believed will enable them to compete in their chosen projects [7]. Tenders are commonly awarded to the lowest tenderer [8]. In addition to these pricing strategies, contract firms can use one or more forms of 
competitive strategies such as the bidding strategy. The tenderer must also formulate a strategy based on the tenderer's own ability.

Established contractor organisations would have a better strategy in the tender because they have had more experiences. However, clients usually face problems with low-value tenders for small contractors and much less attention is given to the predictors of small contractors [9]. Flynn \& Davis [9] revealed that for small contractors, tendering skills and devising buyer engagement strategies are identified as crucial factors alongside with the capability in communication with the suppliers. Usually, small contractors do not have specific staff assigned to complete the tender documents which resulted in incomplete tender information.

Research conducted by Olatunji et al. [10] revealed that the consultant's interpretation of project specifications, previous relationship between the intending bidder and client, availability of other projects at the time of bidding, technological complexity of the project under consideration and prequalification requirements are the influencing factors in deciding the tender. The findings of a study conducted by Aje et al. [11] stated that material availability, labour productivity and level of profit are the most significant factors that highly influenced tender price of construction works and thus the strategy in bidding should focus on these factors.

Based on literature reviewed, this paper proposed four main factors that influenced the decision to bid, namely project characteristics, business benefits, capabilities and bidding situation (refer to Table 1 and Fig. 1). The list grouped under each of the main factors are derived from the factors identified within local and foreign context. Under project characteristics, there are eight factors - size of the project, degree of difficulty, type of procurement method, location, overhead cost, site condition, project special requirements and the availability of materials. Four factors listed under business benefit factor are the company reputation, continuity of business, relationship with previous project and expansion of the organization expertise. Under capabilities factor, there are five contributing factors - technical capabilities for the project, people capabilities that refer to the individual stakeholder of the project, tendering capabilities, project's technology complexity and also tender and contract procedural capabilities. The last factor is the bidding situation whereby six factors were identified. These included tender submission, tender document price, prequalification, previous experience with similar projects, other tenderers' strength and completeness of document.

Table 1 - Factors influencing decision to tender

\begin{tabular}{|c|c|c|c|}
\hline No & & that influence decision making & References \\
\hline 1 & $\begin{array}{l}\text { Project } \\
\text { Characteristics }\end{array}$ & $\begin{array}{l}\text { - Size of the project } \\
\text { - Degree of difficulties } \\
\text { - Type of procurement methods } \\
\text { - Location } \\
\text { - Overhead cost } \\
\text { - Site condition } \\
\text { - Project special requirements } \\
\text { - Availability of materials }\end{array}$ & {$[10],[12],[13]$} \\
\hline 2 & $\begin{array}{l}\text { Business } \\
\text { Benefits }\end{array}$ & $\begin{array}{l}\text { - Company reputation } \\
\text { - Continuity of business } \\
\text { - Relationship with previous project } \\
\text { - Expansion of organization expertise }\end{array}$ & {$[10],[13]$} \\
\hline 3 & Capabilities & $\begin{array}{l}\text { - Technical capabilities for the project } \\
\text { - People capabilities } \\
\text { - Tendering capabilities } \\
\text { - Technology complexity } \\
\text { - Procedural capabilities }\end{array}$ & [9], [10], [13] \\
\hline 4 & $\begin{array}{l}\text { Bidding } \\
\text { Situation }\end{array}$ & $\begin{array}{l}\text { - Tender submission } \\
\text { - Tender document price } \\
\text { - Pre-qualification } \\
\text { - Previous experience with similar projects } \\
\text { - Other tenderers' strength } \\
\text { - Completeness of document }\end{array}$ & {$[10],[12],[13]$} \\
\hline
\end{tabular}

\section{E-Application in Construction Management}

Tendering is a process that results in a successful sales contract. It is a time-consuming and complex industry process that results in a cycle of acceptable liabilities that are contractually linked. Those who are interested in it enter significant construction contracts during the tendering process. The tendering process in this context can be defined as an invitation to relevant parties to make an offer to the principal, who must be capable of accepting the offer, resulting in a legally binding contract [14]. The traditional tendering procedure begins when the project consultant publishes the 
tender announcement through print media such as newspapers within a specific time frame. Following that, the contractor will respond to the tender advertisement by purchasing the documents, filling out the requirements, and submitting the document before the deadline [14].

However, While core architectural, engineering, and quantity surveying functions (such as drawing, engineering design, and bill of quantities preparation, respectively) have been largely computerized, data and document management is still done in the traditional manner in the majority of cases. [13]. The detailed flow of the tender process in the traditional way is shown in Fig. 1 below.

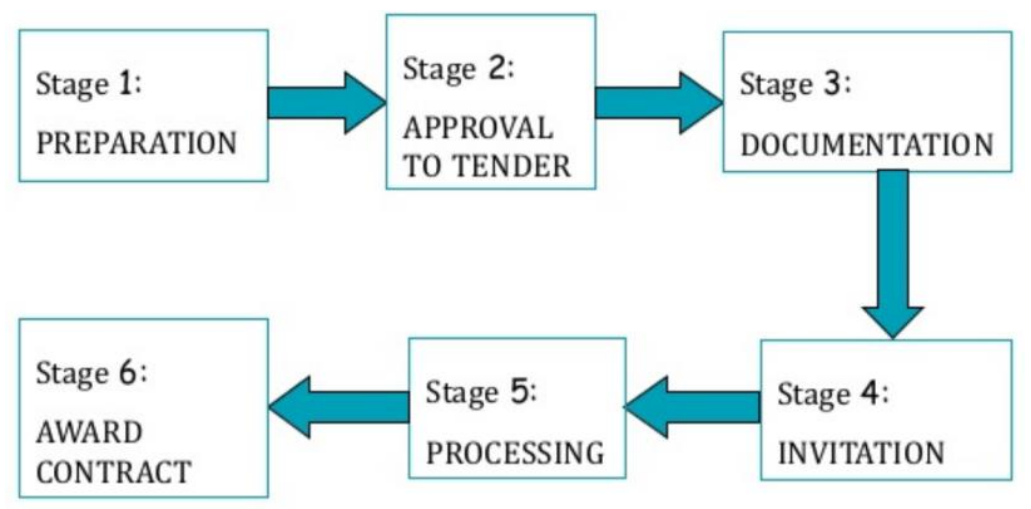

Fig. 1 - Traditional tender process [14]

It is still a common practice for construction industry players to manage documents by hand although some subcontract it to printing or photocopying companies. Documents are still transferred by printing them out and sending them by mail or couriers to the other parties functioning as intermediaries. A slightly more sophisticated method is also in use, in which documents are created digitally and transferred digitally as e-mail attachments. This reduces document transfer time, but in terms of document management, it offers little improvement over the current situation because finding a document in another person's computer can be as difficult as looking for it on shelves. With improvements brought about by revolution in the construction industry, conventional construction techniques and administration methods may no longer meet the requirements of the construction industry [15].

Today, E-applications are highly in demand to deal with the wide range of tasks involved in construction management. It involved all sorts of managerial roles, forms used in the system, varying degree of methods and tools of management. Tools are required to store and process extremely large amounts of information that accumulate over time, and as a result, various types of software for construction management have been developed and made available [16].

Currently, a storage method practice that is becoming more common now is cloud storage where documents are placed on a cloud server and the data can be accessed at any time and from anywhere around the world, provided there is access to the Internet. An example is the sharing of google drive files on the web with authorised personnel. This is referred to as a document management system, in which documents are centrally stored on a server and users interact with this central repository via interfaces implemented using standard web browsers. Electronic document management systems are designed to make it easier to manage documents relevant to specific enterprises, projects, and work groups in computer networks [17]. The evolution of construction management computing device software began with the idea that mathematical, network-based analysis of large-scale projects could save time and money. Since then, software tools with increasing functionality have been developed [17]. Today, software supported project managers in three main tasks in construction management (refer to Fig. 2 and Table 2).

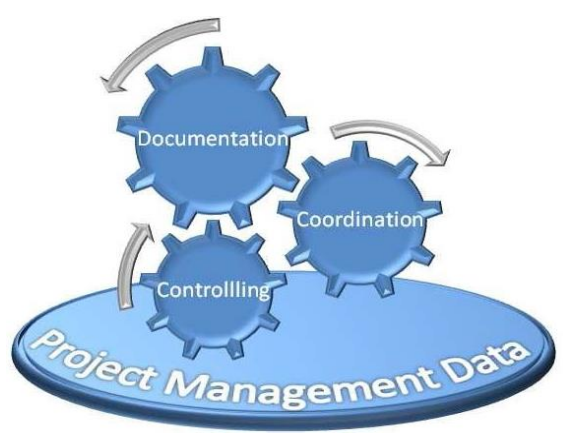

Fig 2 - Project Management Data [15] 
Table 2 - Main tasks in construction management

\begin{tabular}{|c|c|c|}
\hline No & Task & Description \\
\hline 1 & Coordination & $\begin{array}{l}\text { It is not possible to assume that effective communication processes existed in } \\
\text { 'temporary' construction project organisations. The project's division of labour and } \\
\text { responsibilities, as well as the exchange of information and workflow, must be } \\
\text { planned, implemented, and controlled [17]-[18]. }\end{array}$ \\
\hline 2 & Documentation & $\begin{array}{l}\text { In target-oriented control, identifying discrepancies between target and actual } \\
\text { performance was critical. All processes required monitoring within a short time frame } \\
\text { to ensure effective corrective actions could be taken, particularly for quality, cost, and } \\
\text { programme control [17]-[18]. }\end{array}$ \\
\hline 3 & Control & $\begin{array}{l}\text { Coordination, documentation, and control are inextricably linked, and project } \\
\text { management software tools must account for joint data uses, data exchange between } \\
\text { tools, and data exchange with other applications, such as design or tender software. } \\
\text { Unnecessary data collection was reduced, and inconsistencies were avoided, thanks to } \\
\text { clear interfaces [18]. }\end{array}$ \\
\hline
\end{tabular}

Consequently, through increased knowledge, awareness and successful implementation of innovative systems and processes such as electronic tendering (E-Tender), raised interest and expectation of their contribution to the field. Their contributions included 'stimulating' the globalisation of electronic procurement activities, and improving overall business and project performances throughout the construction industry sectors and overall marketplace [19], [20].

\section{Research Methodology}

Based on the literature review, four main factors were identified. The factors are project characteristic, business benefits, organisation capability, and bidding situation (refer to Fig. 3). The factors identified were further investigated through surveys and expert validation.

The questionnaire was used to gauge the potential respondents' point of view on the relevant factors that influenced the decision to tender or not. The potential respondents were the main contractors with CIDB registration under G7 which are publicly listed on CIDB website. The selection of the G7 contractors were based on the size of projects that they were involved in. The questionnaire was divided into two main sections, the first being the list of important factors using a 5-point Likert scale and the second section was an open-ended question requiring the respondents to provide other important factors that was not listed in the questionnaire. The respondents' viewpoint was of utmost importance to ensure the final list derived from this research was a comprehensive list that is reliable and suitable for the local context.

The analytic hierarchy process (AHP) is the data analysis method proposed for this study to rank the factors. The analytic hierarchy process (AHP) is a structured technique for organizing and analysing complex decisions. Based on the AHP analysis outcome, the final list of factors that influenced the decision to tender was identified and validated through expert validation before it was used as the basis to develop the online application. Expert validation was conducted through face-to-face interviews to ensure that the final list of factors is reliable and suitable for the local context. The expert identified must have credentials in the construction industry, is familiar with the tendering process and contractor management. The final list from this stage was used to develop an online application that can help the contractors in decision making, whether or not to tender.

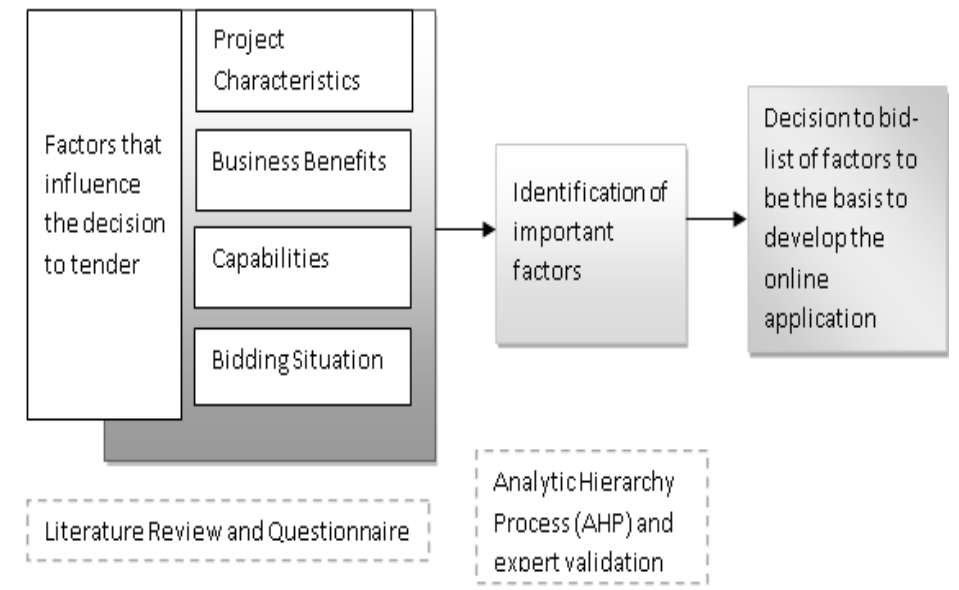

Fig 3 - The research design model 
From the table 1, it can be concluded that factors influencing decision to tender was successfully established. However, the factors provided in the literature review did not fundamentally identified which factors were highly desirable in influencing the decision to tender for a contractor. Moreover, it was not focused on Malaysia and the tendering scenario in Malaysia. The Tender Checklist provided by University of Sydney [14] was used as the basis of the study. Twenty-five (25) items in Table 2 were found to be relevant and included in the questionnaire survey and more factors were to be added as the study progressed.

Table 2 - Tender Checklist [14]

\begin{tabular}{|c|c|c|c|c|c|}
\hline Item & Question & $\begin{array}{c}\text { Project } \\
\text { Characteristics }\end{array}$ & $\begin{array}{l}\text { Business } \\
\text { Benefits }\end{array}$ & Capabilities & $\begin{array}{l}\text { Bidding } \\
\text { Situation }\end{array}$ \\
\hline Q1 & $\begin{array}{l}\text { Have you registered your interest in this } \\
\text { tender? }\end{array}$ & & & & $\mathrm{X}$ \\
\hline Q2 & Do you understand all the requirements? & $\mathrm{X}$ & & $\mathrm{X}$ & $\mathrm{X}$ \\
\hline Q3 & Do you need clarification? & $\mathrm{X}$ & & $\mathrm{X}$ & $X$ \\
\hline Q4 & When is the closing date? & & & & $X$ \\
\hline Q5 & Are you fully informed? & $\mathrm{X}$ & & $X$ & $\mathrm{X}$ \\
\hline Q6 & $\begin{array}{l}\text { Can you complete the entire contract in- } \\
\text { house? }\end{array}$ & & & $\mathrm{X}$ & \\
\hline Q7 & What are the evaluation criteria? & & & & $X$ \\
\hline Q8 & Do you need a tender response strategy? & & & & $\mathrm{X}$ \\
\hline Q9 & $\begin{array}{l}\text { What are the contract terms and } \\
\text { conditions? }\end{array}$ & & & & $\mathrm{X}$ \\
\hline Q10 & What format do you respond in? & & & & $\mathrm{X}$ \\
\hline Q11 & $\begin{array}{l}\text { Are there tenderers' response schedules } \\
\text { given? }\end{array}$ & & & & $\mathrm{X}$ \\
\hline Q12 & $\begin{array}{l}\text { What numbering has been used in the } \\
\text { tender document? }\end{array}$ & & & & $\mathrm{X}$ \\
\hline Q13 & Is your response in a simple format? & & & & $\mathrm{X}$ \\
\hline Q14 & $\begin{array}{l}\text { Have you answered all the specified } \\
\text { requirements? }\end{array}$ & & & & $\mathrm{X}$ \\
\hline Q15 & $\begin{array}{l}\text { Have you provided all the information } \\
\text { requested? }\end{array}$ & & & & $\mathrm{X}$ \\
\hline Q16 & $\begin{array}{l}\text { Have you indicated whether you comply } \\
\text { with the conditions of contract? }\end{array}$ & & & & $\mathrm{X}$ \\
\hline Q17 & $\begin{array}{l}\text { Are there Quality Assurance } \\
\text { requirements? }\end{array}$ & & & $\mathrm{X}$ & \\
\hline Q18 & $\begin{array}{l}\text { Have you demonstrated your ability to } \\
\text { meet all of the selection criteria? }\end{array}$ & & & $\mathrm{X}$ & \\
\hline Q19 & $\begin{array}{l}\text { Have you completed the price or cost } \\
\text { schedule for all items you are tendering? }\end{array}$ & & & $\mathrm{X}$ & \\
\hline Q20 & Are you offering value for money? & & $\mathrm{X}$ & & \\
\hline Q21 & $\begin{array}{l}\text { Have you contacted your referees to } \\
\text { confirm they are willing to be referees? }\end{array}$ & & & $\mathrm{X}$ & \\
\hline Q22 & Have there been any amendments? & & & & $\mathrm{X}$ \\
\hline Q23 & Is this an alternative tender? & & & & $\mathrm{X}$ \\
\hline Q24 & $\begin{array}{l}\text { Have you signed all the appropriate } \\
\text { forms? }\end{array}$ & & & & $\mathrm{X}$ \\
\hline Q25 & How can you send your response? & & & & $\mathrm{X}$ \\
\hline
\end{tabular}

\section{Conclusion}

This paper is a part of an on-going research on a strategy to help the contractor to decide whether or not to tender in the tendering decision phase. The purpose of this paper was to identify the important factors to be considered in making bidding decision for construction projects, based on extensive literature reviews. This paper highlighted the major factors considered by contractors in Malaysia and other parts of the world. There were four main factors identified. They included project characteristics, business benefits, organisation capability, and the bidding situation. The findings of this study served as a basis to proceed to the next stage of statistical analysis, which is to identify the important hierarchy of the factors which required more thorough investigation within local context. It was important to set a scope in the findings based on the local context to ensure that the outcome was to the advantage of the local contractors. 


\section{Acknowledgement}

Authors wished to acknowledge the financial assistance and encouragement received from The Management of Universiti Teknologi MARA Cawangan Sarawak.

\section{References}

[1] Eusoff N. S. (2017). CIDB: Malaysia's Construction Sector Grow by 8\% This Year. https://www.theedgemarkets. com/article/cidb-malaysias-construction-sector-grow-8-year

[2] Economic Planning Unit (2015). Eleventh Malaysian Plan 2016 - 2020 Anchoring Growth of People. Economic Planning Unit Prime Minister Department, pp. 58

[3] Ashworth A. \& Perera S. (2018). Contractual Procedures in The Construction Industry. Routledge, pp. 18-24.

[4] Kog F. \& Yaman H. (2016). A multi-agent systems-based contractor pre-qualification model. Engineering, Construction and Architectural Management, 23 709-726

[5] Jarkas A. M. (2017). Contractors' perspective of construction project complexity: Definitions, principles, and relevant contributors. Journal of Professional Issues in Engineering Education and Practice, 143, 04017007

[6] De Araújo M. C. B., Alencar L. H. \& de Miranda Mota C. M. (2017). Project procurement management: A structured literature review. International Journal of Project Management, 35, 353-377

[7] Urquhart S., Whyte A. \& Lloyd N. (2017). The development of a more efficient internal tender procedure framework for Australian construction contractors. Proceeding of the 33rd Annual ARCOM Conference, Cambridge

[8] Loosemore M. \& Richard J. (2015). Valuing innovation in construction and infrastructure: Getting clients past a lowest price mentality. Engineering, Construction and Architectural Management, 22, 38-53

[9] Flynn A. \& Davis P. (2017). Investigating the effect of tendering capabilities on SME activity and performance in public contract competitions. International Small Business Journal, 35, 449-469

[10] Olatunji O. A., Aje O. I. \& Makanjuola S. (2017). Bid or no-bid decision factors of indigenous contractors in Nigeria. Engineering, Construction and Architectural Management, 24, 378-392

[11] Aje I. O., Oladinrin T. O. \& Nwaole A. N. C. (2016). Factors influencing success rate of contractors in competitive bidding for construction works in South-East, Nigeria. Journal of Construction in Developing Countries, 21, 19-34

[12] Bagies A. \& Fortune C. (2006). Bid/no bid decision modelling for construction projects. Proceeding the 22nd Annual ARCOM Conference, Birmingham

[13] Biruk S., Jaśkowski P. \& Czarnigowska A. (2017). Modeling contractor's bidding decisions. Procedia Engineering, 182, 91-98

[14] University of Sydney (2020). Tender Checklist. https://www.sydney.edu.au/content/dam/corporate/documents/ about-us/working-with-the-university/suppliers/tender-checklist.pdf

[15] The Chartered Institute of Building (2019). Computers in The Management of Construction. https://www. designingbuildings.co.uk/wiki/Computers_in_the_management_of_construction

[16] Al-Qazzaz I. (2010). Information Technology in Construction. https://www.academia.edu/34573031/Information_ Technology_in_Construction

[17] El Paso County, Texas (2011). Project Coordination Plan. https://ftp.dot.state.tx.us/pub/txdot-info/ elp/projects/ border_highway_west/ coordination_plan.pdf

[18] Constructions Tut (2016). 10 Documents Must Be Included on Every Construction Project. https://www.constructiontuts.com/documents-for-construction-project/

[19] Ezanee M. E., Norlila M. \& Nurshuhada S. (2005). E-Tendering System for Construction Projects. Procurement International Conference on E-Commerce 2005, Selangor

[20] Mastor S. H. \& Azizan A. Z. (2012). E-Tender application and its implication to Malaysian construction industry. International Conference on Technology management 2006 (ICTM 2006), Putrajaya 